\title{
SAFEGUARDING EQUALITY FOR THE HANDICAPPED: COMPENSATORY RELIEF UNDER SECTION 504 OF THE REHABILITATION ACT
}

The Rehabilitation Act of $1973^{1}$ (the "Rehabilitation Act" or the "Act") established a comprehensive federal plan aimed at improving the opportumities available to handicapped persons. Section $504,{ }^{2}$ the central provision of the Act, prohibits discrimination against "otherwise quahfied handicapped individuals" 3 in programs or activities that receive federal financial assistance. ${ }^{4}$ Although section 504 does not explicitly establish a private right of action against discriminatory programs, ${ }^{5}$ federal courts have uniformly agreed that an individual right of action is implied. ${ }^{6}$ There has been much less agreement, however, on the question whether a compensatory dainages remedy is available in an action

1. Pub. L. No. $93-112,87$ Stat. 355 (codified as amended at 29 U.S.C. $\$ \S 701-794$ (1982)).

2. Id. $\S 504,87$ Stat. 355,394 (codified as amended at 29 U.S.C. $\$ 794$ (1982)). The section provides in part: "No otherwise qualified handicapped individual ... shall, solely by reason of his handicap, be excluded from the participation in, be denied the benefits of, or be subjected to discrimination under any program or activity receiving Federal financial assistance or under any program or activity conducted by any Executive agency or by the United States Postal Service." Id.

3. According to the rules issued under section 504, a handicapped person is "otherwise qualified" if the individual, with reasonable accommodation, is capable of performing the "essential elements" of the task in question. See, e.g., 34 C.F.R. $\$ 104.3(\mathrm{k})(1)$ (1985) (Department of Education rules); 45 C.F.R. $\$ 84.3(\mathrm{k})(1)(1985)$ (Health and Human Services rules).

4. 29 U.S.C. $\$ 794$ (1982).

5. For a discussion of the absence of an explicit right of action under section 504, see Wegner, The Antidiscrimination Model Reconsidered: Ensuring Equal Opportunity Without Respect to Handicap Under Section 504 of the Rehabilitation Act of 1973, 69 CORNELL L. REv. 401, 41416 (1984); Comment, Rehabilitation Act of 1973: Is There An Implied Right of Action Under Section 504?, 49 TENN. L. REV. 577, 592-93 (1982).

6. Courts of appeals in ten circuits have held that section 504 unplicitly confers a private right of action. See Jennings v. Alexander, 715 F.2d 1036, 1040-41 (6th Cir. 1983), rev'd on other grounds sub nom. Alexander v. Choate, 105 S. Ct. 712 (1985); Jones v. Metropolitan Atlanta Rapid Transit Auth., 681 F.2d 1376, 1377 n.1 (11th Cir. 1982), cert. denied, 465 U.S. 1099 (1984); Miener v. Missouri, 673 F.2d 969, $973-75$ (8th Cir.), cert. denied, 459 U.S. 909 (1982); Pushkin v. Regents of the Univ. of Colo., 658 F.2d 1372, 1376-80 (10th Cir. 1981); Simon v. St. Louis County, 656 F.2d 316, 319-20 (8th Cir. 1981), cert. denied, 455 U.S. 976 (1982); Kling v. Cormty of Los Angeles, 633 F.2d 876, 878 (9th Cir. 1980), rev'd on other grounds; 106 S. Ct. 300 (1985); Carmi v. Metropolitan St. Louis Sewer Dist., 620 F.2d 672, 674-75 (8th Cir.), cert. denied, 449 U.S. 892 (1980); Camenisch v. University of Tex., 616 F.2d 127, 131 (5th Cir. 1980), vacated on other grounds, 451 U.S. 390 (1981); NAACP v. Medical Center, Inc., 599 F.2d 1247, 1258-59 (3d Cir. 1979); Davis v. Southeastern Community College, 574 F.2d 1158, 1159 (4th Cir. 1978), rev'd on other grounds, 442 U.S. 397 (1979); Kampmeier v. Nyquist, 553 F.2d 296, 299 (2d Cir. 1977); Lloyd v. Regional Transp. Auth., S48 F.2d 1277, 1284-87 (7th Cir. 1977). 
brought under section $504 .^{7}$

In 1978, Congress amended the Rehabilitation Act (the "1978 amendments"), ${ }^{8}$ intending to eliminate the uncertainty as to the types of relief available to victims of discrimination against the handicapped. Included among the 1978 amendments was section 505(a)(2), ${ }^{9}$ which provides that the "remedies, procedures, and rights set forth in title VI of the Civil Rights Act of 1964 shall be available to any person aggrieved by any act or failure to act by any recipient of Federal assistance or Federal provider of such assistance under section 504 of this Act."10 Courts had previously allowed declaratory and mjunctive relief in title VI actions, ${ }^{11}$ and accordingly section 505(a)(2) makes such relief available to a section 504 plaintiff. Title VI, however, like section 504, neither explicitly permits nor proscribes a damages remedy. In addition, at the time Congress enacted section 505(a)(2), the Supreme Court had not yet declared that compensatory relief was available under title VI. ${ }^{12}$ Thus, questions concerning the availability of compensatory relief to the section 504 plaintiff continue to be hitigated.

This note examines the debate on the existence of a damages remedy under section 504. The note reviews the Rehabilitation Act and the congressional purpose underlying it. ${ }^{13}$ The note then identifies the administrative remedies provided by regulations promulgated to implement the Act $^{14}$ and analyzes relevant federal court decisions. ${ }^{15}$ The note concludes that the protection afforded the handicapped under section 504 necessarily implies the right to compensatory rehef.

This note also considers what showing a private plaintiff must make

7. Compare Miener v. Missouri, 673 F.2d 969, $977-79$ (8th Cir.) (damages available under section 504), cert denied, 459 U.S. 909 (1982) with Ruth Anne M. v. Alvin Indep. School Dist., 532 F. Supp. 460, 46473 (S.D. Tex. 1982) (damages not available under $\S 504$ ).

8. Rehabilitation, Comprehensive Services and Developmental Disabilities Amendments of 1978, Pub. L. No. 95-602, 92 Stat. 2955 (codified in scattered sections of 29 U.S.C. $\$ \S 701-794$ (1982)) [hereinafter cited as 1978 amendments].

9. $X d . \$ 120$ (codified at 29 U.S.C. $\$ 794 \mathrm{a}(\mathrm{a})(2)(1982)$ ).

10. Id. Title VI prohibits racial discrimination by employers and agencies that receive federal funds earmarked to provide employment. 42 U.S.C. $\$ \$ 2000$ d to $2000 \mathrm{~d}-6$ (1982).

11. See, e.g., Drayden v. Needville Indep. School Dist., 642 F.2d 129, 132-33 (5th Cir. 1981); Concerned Tenants Ass'n v. Indian Trails Apartments, 496 F. Supp. 522,527 (N.D. IIl. 1980).

12. The question of the availability of damages under title VI was addressed in Guardians Ass'n v. Civil Serv. Comm'n, 463 U.S. 582 (1983). Though no opinion commanded a majority, the decision establishes that compensatory relief is available under that statute, but only for intentional violations. Id. at $607 \mathrm{n} .27$ (opinion of White, J., announcing the judgment of the Court); see also infra notes 78-83 and accompanying text. This case was decided five years after the passage of the 1978 amendments to the Rehabilitation Act.

13. See infra notes $37-49$ and accompanying text.

14. See infra notes $50-60$ and accompanying text.

15. See infra notes $61-81$ and accompanying text. 
in order to be entitled to compensatory relief under section 504. ${ }^{16}$ Specifically, the note addresses the question whether the plaintiff must prove discriminatory intent. This inquiry focuses on the Supreme Court's decision in Guardians Association v. Civil Service Commission, ${ }^{17}$ where a majority of the Justices limited compensatory relief under title VI to cases in which intentional discrimination is proven. ${ }^{18}$ Because section 505(a)(2) links the remedies available under section 504 to those available under title VI, some courts concluded from Guardians that damages may be awarded in a section 504 action, but only after a showing of purposeful discrimination. ${ }^{19}$ This note demonstrates the mappropriateness of a standard requiring proof of discriminatory intent, ${ }^{20}$ and concludes that compensatory relief should be awarded not only to the plaintiff who has been subjected to deliberate discrimination but also to the plaintiff who has suffered from discriminatory effects that could have been avoided had the fund recipient inade reasonable accommodation to account for the plaintiff's handicap. ${ }^{21}$

\section{Section 504 of the Rehabilitation Act}

\section{A. Private Cause of Action.}

With the Rehabilitation Act, Congress introduced aggressive measures designed to bring handicapped citizens into the mainstream of American society. Section 504 of the Act constituted the first national declaration of the civil riglits of the handicapped. In addition to guaranteeing equal rights for disabled individuals in federally aided programs, ${ }^{22}$ the Act provides for certain procedures designed to integrate handicapped individuals into the community through expanded educational and employment opportunities. ${ }^{23}$ The Act recognizes that handicapped

\footnotetext{
16. See infra notes $82-120$.

17. 463 U.S. 582 (1983).

18. Id. at 607 n.27 (opinion of White, J., announcing the judgment of the Court); see also infra notes 82-83 and accompanying text.

19. See Carter v. Orleans Parish Pub. Schools, 725 F.2d 261, 264 (5th Cir. 1984); Marvin H. v. Austin Indep. School Dist., 714 F.2d 1348, 1357 (5th Cir. 1983); Sabo v. O’Bannon, 586 F. Supp. 1132, 1138 (E.D. Pa. 1984). But see Wilder v. City of New York, 568 F. Supp. 1132, 1136 (E.D.N.Y. 1983) (damages available without proof of discriminatory pnrpose).

20. See infra notes $92-99$ and accompanying text.

21. See infra notes 100-20 and accompanying text.

22. See supra note 2 and accompanying text.

23. Section 501 of the Act requires federal agencies to take affirmative action to hire disabled persons. 29 U.S.C. $\$ 791$ (b) (1982). Section 502 creates the Architectural and Transportation Barriers Compliance Board to resolve problems created by structural and transportation barriers. Id. $\$ 792$. Section 503 requires federal contractors employed under contracts worth more than $\$ 2500$ to take affirmative stcps toward hiring disabled persons. Id. \$ 793(a). See Wegner, supra note 5, at 403 n.5.
} 
persons can become substantially more productive once they receive basic training and accordingly encourages the development of rehabilitation services for even the most severely disabled. ${ }^{24}$ The Rehabilitation Act thus seeks to integrate of handicapped individuals into mainstream society as productive and independent citizens.

Aggressive implementation of the Act was not immediately forthcoming. Although Congress had indicated that each agency administering federally funded programs should promulgate regulations to implement section 504,25 no government agency imitiated major steps toward enforcement.26 Even the Department of Health, Education and Welfare (HEW), ${ }^{27}$ which was responsible for coordinating the implementation of section 504,28 proceeded sluggishly. ${ }^{29} \mathrm{HEW}$ did not issue its first set of regulations until four years after the enactment of section $504^{30}$ and then only in response to a federal court order. ${ }^{31}$

As federal departments and agencies moved slowly in enforcing section 504, handicapped individuals who had been subjected to discriminatory treatment turned to the courts for relief. Although the Rehabilitation Act as originally enacted did not specifically outline a course of remedial action for individual plaintiffs, the 1978 amendments and their legislative history clearly support the view that section 504 does afford a private right of action. ${ }^{32}$ The federal courts of appeals have uni-

24. See 29 U.S.C. $\$ 723$ (1982) (scope of vocational rehabilitation services provided under Rehabilitation Act); see also The 504 Notice: Moving Toward a Civil Rights Act, AMICuS, July 1976, at 12 (discussing potential for increased productivity of disabled persons who receive rehabilitative assistance).

25. See S. REP. No. 1297, 93d Cong., 2d Sess. 39-40, reprinted in 1974 U.S. CODE CoNG. \& AD. NEws 6373, 6390-91.

26. See Note, Accommodating the Handicapped: Rehabilitating Section 504 after Southeastern, 80 Colum. L. REV. 171, 176 n.25 (1980).

27. In 1980, Congress replaced HEW with two new departments, the Department of Edueation and the Department of Health and Human Services (HHS). Department of Education Organization Act, Pub. L. No. 96-88, $\S ~ 201,509,93$ Stat. 671, 695 (1979) (codified at 20 U.S.C. $§ 3411,3508$ (1982)). Both Departments have promulgated regulations on section 504. See 45 C.F.R. pt. 84 (1983) (HHS regulations); 34 C.F.R. pt. 104 (1983) (Department of Education regulations).

28. To hasten the drafting of regulations, President Gerald Ford issued an executive order in 1976 specifically providing that HEW oversee the implementation of section 504. Exec. Order No. 11,914, 3 C.F.R. 117-18 (1977), reprinted in 29 U.S.C. \$ 794 app. at 1074 (1982), revoked by Exec. Order No. 12,250, 3 C.F.R. 300 (1981), reprinted in 42 U.S.C. $\$ 2000$ d-1 app. at 23 (1982).

29. See Note, supra note 26 , at 176 n.25.

30. 45 C.F.R. pt. 84 (1977).

31. Cherry v. Mathews, 419 F. Supp. 922,924 (D.D.C. 1976) (ordering Secretary of HEW to promulgate regulations effectuating section 504).

32. For example, section 505(b) of the Act, added in 1978, provides for an award of attorneys' fees in actions brought to enforce section 504 rights. 1978 Amendments, supra note 8, $\$ 120,92$ Stat. 2955, 2982 (codified at 29 U.S.C. $\$ 794 a(b)$ (1982)). In explaining the purpose of this provision, the pertinent House report states: 
formly embraced this view. ${ }^{33}$ Although the Supreme Court has not directly addressed this issue, ${ }^{34}$ the analysis of the lower courts is supported by Supreme Court decisions recognizing implied riglits of action under otlier federal statutes. ${ }^{35}$

[D]isabled individuals are one of the very few minority groups in this country who have not been authorized by Congress to seek attorney's fees. The amendment [section 505(b)] proposes to correct this omission and thereby assist handicapped individuals in securing the legal protection guaranteed them under Title $\mathrm{V}$ of the [Rehabilitation Act].

H.R. REP. No. 1149, 95th Cong., 2d Sess. 21, reprinted in 1978 U.S. Code CoNG. \& AD. NEwS 7312,7332 .

33. See supra note 6 .

34. The Court had its first opportunity to construe the rights accorded under section 504 in Southeastern Community College v. Davis, 442 U.S. 397 (1979). Frances Davis, a twenty-nine-yearold student who suffered from a hearing disorder, asserted that Southeastern Community College rejected her apphication for admission to a nursing program because of her impairment. Noting that Davis could not meet the necessary requirements for safe and effective participation in the nursing program because of her hearing disorder, the Court held that Davis was not an "otherwise qualified handicapped individual" and thus was not in the class of persons protected by section 504. Id. at 406, 409-14. The Court thus did not decide whether a person in a benefited class had a private right of action.

In a more recent case, Consolidated Rail Corp. v. Darrone, 465 U.S. 624 (1984), petitioner Conrail abandoned its argument against the existence of a private right of action before the Court could consider the issue. Id. at 630 n.7. The Court, however, noted that the lower courts had held that a private right of action is available. Id.

35. A number of the lower courts have rehed on the type of analysis used by the Supreme Court in Cort v. Ash, 422 U.S. 66 (1975), and Cannon v. University of Chicago, 441 U.S. 677 (1979). See, e.g., Miener v. Missouri, 673 F.2d 969, 973-75 (8th Cir.) (relying on Cort and Cannon to imply a cause of action under section 504), cert. denied, 459 U.S. 909 (1982). The Supreme Court acknowledged such use of Cannon by the lower courts in Consolidated Rail Corp. v. Darrone, 465 U.S. 624, 630 n.7 (1984).

In Cannon, the Court used four factors first articulated in Cort to determine whether Congress intended to estabhish a private right of action under title IX of the Education Amendments of 1972:

First, is the plaintiff "one of the class for whose especial benefit the statute was enacted,"that is, does the statute create a federal right in favor of the plaintiff? Second, is there any indication of legislative intent, explicit or implicit, either to create such a remedy or to deny one? Third, is it consistent with the underlying purposes of the legislative scheme to imply such a remedy for the plaintiff? And finally, is the cause of action one traditionally relegated to state law, in an area basically the concern of the States, so that it would be inappropriate to infer a cause of action based solely on federal law?

Cannon, 441 U.S. 677, 688 n.9 (1979) (quoting Cort v. Ash, 422 U.S. 66, 78 (1975) (emphasis in original) (quoting Texas \& Pac. Ry. Co. v. Rigsby, 241 U.S. 33, 39 (1916))) (citations omitted). Cases since Cannon have emphasized that, in determining whether a private right of action is to be implied, the initial focus should be on legislative intent. See Merrill Lynch, Pierce, Fenner \& Smith, Inc. v. Curran, 456 U.S. 353, 378 (1982); Middlesex County Sewerage Auth. v. National Sea Clainmers Ass'n, 453 U.S. 1, 13 (1981). As noted previously, supra note 32 and accompanyiug text, the legislative history of section 505(b) of the Act, added with the 1978 amendments, demonstrates that Congress regarded section 504 as affording a private right of action. Moreover, the legislative history of the Rehabilitation Act Amendments of 1974, Pub. L. No. 93-516, 92 Stat. 1617, indicates that Congress intended to use title VI as a model for remedies available under section 504. See, e.g., S. REP. No. 1297, 93d Cong., 2d Sess. 39, reprinted in 1974 U.S. CODE CONG. \& AD. NEws 6373, 6390 (section 504 "patterned after and almost identical to, the antidiscrimination language" of title VI). 


\section{B. Availability of Damages.}

The general agreement among the courts of appeals that section 504 confers a private judicial remedy leaves unresolved the question whether compensatory rehief can be awarded under the statute. As the Supreme Court noted in Davis v. Passman, "[W] action' is analytically distinct and prior to the question of what relief, if any, a litigant may be entitled to receive." 36

1. Congressional Purpose. Congress passed no explicit measure allowing monetary damages. The legislative listory of the Act, especially on the subject of damages, is not detailed. ${ }^{37}$ It is generally accepted, however, that federal courts may employ any available remedy to right a wrong when legal rights liave been invaded. ${ }^{38}$ The availability of damages is arguably most compelling where damages "are necessary to make effective the congressional purpose." 39

Congress openly stated its intention to encourage the "vocational rehabilitation and independent living" of liandicapped persons through the "guarantee of equal opportunity." 40 The handicapped person, one Senate report explained, "is all too often excluded from schools and educational programs, barred from employment or is underemployed because of arcliaic attitudes toward the handicapped, denied access to transportation, buildings and housing because of architectural barriers and lack of planning, and is discriminated against by our public laws."41 Congress therefore passed the Rehabilitation Act after realizing that a pernicious, thougl often not conscious, prejudice harmed disabled citizens by denying them educational, employment, and other opportunities comparable to those enjoyed by the inajority of Americans. ${ }^{42}$

Yet im protecting the handicapped from such discrimination, Con-

36. 442 U.S. 228, 239 (1979); see also Guardians Ass'n. v. Civil Service Comm'n, 463 U.S. 582, 595 (1983) (opinion of White, J., announcing the judgment of the Court) (quoting Davis v. Passman, 442 U.S. 228, 239 (1979)).

37. See Lloyd v. Regional Transp. Auth., 548 F.2d 1277, 1285 (7th Cir. 1977) ("legislative history of Section 504 is bereft of much explanation").

38. Bell v. Hood, 327 U.S. 678,684 (1946).

39. J.I. Case Co. v. Borak, 377 U.S. 426, 433 (1946); see also Bivens v. Six Unknown Named Agents, 403 U.S. 388, 402 \& n.4 (1971) (Harlan, J., concurring in the judgment) ("[T]his Court has authorized . . . relief [in the form of damages] where, in its view, damages are necessary to effectuate the congressional policy underpinning the substantive provisions of the statute.").

40. 29 U.S.C. $\S 701$ (1982).

41. S. ReP. No. 319, 93d Cong., 1st Sess. 2 (1973).

42. Cf. 118 CONG. REC. 3320-21 (1972) (statement of Sen. Williams) (noting the existence of unequal opportunity for handicapped persons while introducing a bill and a resolution to study and to coordinate programs for the handicapped). 
gress chose to regulate only programs that accepted federal funds. ${ }^{43}$ Indeed, the Act states that " $[\mathrm{t}] \mathrm{he}$ purpose of this Act is . . to authorize programs" to provide opportunities for the handicapped. ${ }^{44}$ It can be argued that Congress, in selecting this scheme of regulation, sought to protect group rights and advance group opportumities ${ }^{45}$ rather than to protect the rights of individual victims of discrimination. ${ }^{46}$ Accordingly, enforcement of an individual's rights where enforcement would impinge on the opportunities available to the group would seem to be contrary to congressional purpose. In this sense, it could be argued that compensatory relief should not be available under section 504, because the payment of money awards decreases the funds available to the program in question, and thereby diminishes the overall availability of group opportumities. ${ }^{47}$

In another sense, however, an award of compensatory damages in an action brought by an individual handicapped person agamst a discriminatory program enhances the opportunities available to all handicapped persons. The availability of compensatory relief encourages federally funded programs to provide the legislatively mandated opportunities for handicapped persons; im short, it deters discrimination. ${ }^{48}$ Thus,

43. Section 504 prohibits discrimination against handicapped persons only in programs and activities receiving federal funds. 29 U.S.C. $\$ 794$ (1982).

44. Rehabilitation Act of 1973, Pub. L. No. 93-112, § 2, 87 Stat. 355, 357 (einphasis added) (section entitled "Declaration of Purpose"). This statement of purpose was amended by the 1978 amendinents, supra note 8, to state that the purpose "was to develop and implement . . comprehensive programs of vocational rehabilitation and independent living." 1978 amendinents, supra note 8, $\S 2$, 92 Stat. 2955, 2984 (codified at 29 U.S.C. $\$ 701$ (1982)).

45. See Ruth Anne M. v. Alvin Indep. School Dist., 532 F. Supp. 460, 471-73 (S.D. Tex. 1982) (finding that Congress created an individual cause of action to facilitate enforcement, not to create a right to damages).

46. Title VII, which prohibits racial discrimination in employment practices, authorizes refief sufficient to make the aggrieved individuals whole, i.e., place them in the position they would have occupied but for the discriminatory practices. See Franks v. Bowman Transp. Co., 424 U.S. 747, 763 (1976). Compensatory relief can be granted regardless of financial consequences to the private employer. Such relief may have a net effect of eliminating opportunities for of inimority employees. Cf. R. POSNER, ECONOMIC ANALysis of LAw 536 (2d ed. 1977) (noting that laws forbidding discrinination in workplace may not improve net welfare of victims of discrimination); Landes, The Economics of Fair Employment Laws, 76 J. PoL. EcoN. 507, 523-24 (1968) (empirical study noting that laws requiring blacks to be paid as much as whites caused disenployment of blacks).

47. See Ruth Anne M. v. Alvin Indep. School Dist., 532 F. Supp. 460, 473 (S.D. Tex. 1982) (awarding damages would be inconsistent with purposes of Rehabilitation Act).

48. Richard Posner makes the same point in discussing the relationship of negligence and compensatory damages in the law of torts:

The association of negligence with purely compensatory damages has prompted the erroneous impression that liability for negigence is intended solely as a device for compensation. Its economic function is different; it is to deter uneconomical accidents. As it happens, the right amount of deterrence is produced by coinpelling negligent injurers to make good the victim's losses. Were they forced to pay more (punitive damages), soine economical accidents might also be deterred; were they pernitted to pay less than compensation, some 
to the extent that compensatory relief enhances the opportunities of handicapped persons as a group, its availability is justifiable as a means to effectuate the congressional purpose..$^{49}$

2. Administrative Remedies. In determining whether a damages remedy should be available under a statute creating liability, courts often first ask whether the rights afforded by the statute are sufficiently safeguarded by administrative remedies. ${ }^{\text {so }}$ Although a handicapped individual alleging discrimination is entitled to file a complaint with the federal agency that funds the activity in question, 51 the administrative remedies available to correct violations of section 504 are, for the most part, inadequate. In the first place, vigorous enforcement of section 504 is unlikely. As one commentator explained:

Because a particular [federal] agency is responsible for both enforcing section 504 and implementing the programs a section 504 complaint will necessarily attack, there is a built-in conflict of interest and a resulting reluctance to enforce section 504. Self-survival dictates that agencies attempt to look as effective as possible in the implementation of their programs. Similarly, close relationships are naturally developed between agencies and those programs and other recipients they fund. It is impractical to expect these same agencies to strain established relationships by stringent enforcement of section 504.52

Because of this inherent conflict of interest, one cannot reasonably anticipate that federal agencies will sufficiently protect victims' interests. Enforcement of section 504 will be, at best, a secondary goal.

Moreover, an individual wlio files a complaint with the appropriate agency has no guarantee of a thorough administrative inquiry. The regulations of the Department of Health and Human Services, for example, give the complamant no explicit right to take part in the agency's investigation $^{53}$ or seek review of agency findings. ${ }^{54}$ Moreover, the complainant

uneconomical accidents would not be deterred. It is thus essential that the defendant be made to pay damages....

R. POSNER, supra note 46, at 143.

49. Because the availability of compensatory relief to private plaintiffs also lias the potential to eliminate group opportunities by reducing the funds available to programs aiding the handicapped, defining the standard of conduct that triggers compensatory relief is crucial. See infra notes 82-120 and accompanying text (discussing different standards for recovery).

50. See Miener v. Missouri, 673 F.2d 969, $977-78$ (8th Cir.) (discussing inadequacy of administrative remedies and determining that damages remedy is available under section 504), cert. denied, 459 U.S. 909 (1982); Pushkin v. Regents of the Univ. of Colo., 658 F.2d 1372, 1381 (10th Cir. 1982) (same).

51. See, e.g., 45 C.F.R. $\$ 80.7$ (b) (1985) (HHS rule for title VI, applicable to the Rehabilitation Act pursuant to 45 C.F.R. $\$ 84.61$ (1985)).

52. Comment, supra note 5 , at 587 (citations omitted).

53. See, e.g., 45 C.F.R. $\$ 80.7$ (c) (1985) (HHS rule for title VI, applicable to the Rehabilitation Act pursuant to 45 C.F.R. $\S 84.61$ (1985)).

54. Id. $\S 80.7(d)(2)$. 
is not a party to any proceedings resulting from the coinplaint, but may only petition to become an amicus curiae. ${ }^{55}$ In short, a disabled person can gain "ittle comfort" from the languid enforceinent such regulatory provisions countenance, ${ }^{56}$ and violators of the Act can only be encouraged by the obstacles thus posed to effective administrative enforcement.

Additionally, the remedies available under the regulations are not sufficiently attractive to encourage the victims of discrimination to pursue a coinplaint and are inadequate to deter misconduct in the first place. The administrative procedures promulgated under the Rehabilitation Act furnish no means by which a disabled person who has been injured by discriminatory treatment can be coinpensated; the availability of prospective relief neither provides an adequate inducement to private plaintiffs to bring suit nor encourages recipients of federal funding to take steps before a complaint is filed to correct conditions violative of section 504. The most severe administrative sanction-the termination of federal financial support to defendant programs ${ }^{57}$-is seldom employed..$^{58}$ Moreover, the imposition of this sanction only has the effect of punishing the program. The complainant and other handicapped individuals are not aided by the termination of funds, and the purpose of the Act is thus defeated. ${ }^{59}$ Without the possibility of a dannage award, plaintiffs with meritorious clains may well be discouraged from pursuing section 504 actions. By encouraging victims of section 504 violations to sue, a damages remedy effectuates congressional purpose more fully than does the administrative enforcement currently in place. ${ }^{60}$

\section{Id. $\$ 81.23$.}

56. Miener v. Missouri, 673 F.2d 969, 978 (8th Cir.), cert. denied, 459 U.S. 909 (1982).

57. See, e.g., 45 C.F.R. $\$ 80.8$ (1985) (HHS rule).

58. See Guardians Ass'n v. Civil Serv. Comm'n, 463 U.S. 582, 626-27 (1983) (Marshall, J., dissenting) (statutory fund cutoff cannot adequately provide compensation or ensure compliance with the law); see also Lamber, Private Causes of Action Under Federal Agency Nondiscrimination Statutes, 10 CONN. L. REv. 859, 888 n.150 (1978) (because of its extreme and harsh nature, cutoff sanction only employed three times in first fourteen years following enactment of title VI).

59. See Camenisch v. Umiversity of Tex, 616 F.2d 127, 135 (5th Cir. 1980), vacated on other grounds, 451 U.S. 390 (1981).

60. Some courts, though acknowledging the availability of a private right of action, have held that a section 504 plaintiff must exhaust administrative remedies before bringing a private action. See, e.g., Rettig v. Kent City School Dist., 539 F. Supp. 768, 771 (N.D. Ohio 1981), aff'd in part and vacated in part, 720 F.2d 463 (6th Cir. 1983), cert. denied and appeal dismissed, 467 U.S. 1201 (1984); Stubbs v. Kline, 463 F. Supp. 110, 117 (W.D. Pa. 1978). But see Miener v. Missouri, 673 F.2d 969, 978-79 (8th Cir.) (exhaustion of administrative remedies not required), cert. denied, 459 U.S. 909 (1982); Kling v. County of Los Angeles, 633 F.2d 876, 879 (9th Cir. 1980) (same), rev'd on other grounds, $106 \mathrm{~S}$. Ct. 300 (1985). Those courts rejecting the exhaustion requirement seem to have the better argument, at least with respect to federal administrative remedies. In Cannon v. University of Chicago, 441 U.S. 677 (1979), the Supreme Court rejected an exhaustion requirement 
3. Lower Federal Courts. Some lower federal courts have concluded that damages may be awarded to vindicate rights established by section 504.61 In Miener v. Missouri, ${ }^{62}$ for example, the United States Court of Appeals for the Eighth Circuit recognized the need for a damages remedy, noting that other remedial procedures were "inadequate" to protect the rights of handicapped persons. ${ }^{63}$ Although it disallowed recovery of damages from state officials on eleventh amendment grounds, the court read section 504 to allow a damages remedy. ${ }^{64}$ And in Christopher N. v. McDaniel, ${ }^{65}$ a federal district court, referring to the general principle that the right to seek compensatory relief for violations of a citizen's personal liberty is "an accepted feature of tlie American judicial system," likewise lield that damages may be awarded to section 504 plaintiffs. ${ }^{66}$

In Ruth Anne M. v. Alvin Independent School District, ${ }^{67}$ however, a federal district court concluded otlerwise. The court determined that Congress intended to establish a judicial remedy to protect the entitlement of disabled individuals to equal opportumity. ${ }^{68}$ The court held, lowever, that this remedy was limited to injunctive or declaratory rehef. ${ }^{69}$ Altlough it recognized that a damages remedy would enhance the

for a private action under title IX of the Education Amendments of 1972. Id. at 706 n.42. Both title IX and section 504 are modeled on title VI. See supra note 35.

61. See Carter v. Orleans Parish Pub. Schools, 725 F.2d 261, 264 (5th Cir. 1984) (damages available upon proof of discriminatory intent); Marvin H. v. Austin Indep. School Dist., 714 F.2d 1348, 1357 (5th Cir. 1983) (same) (dictum); Miener v. Missouri, 673 F.2d 969, $977-79$ (8th Cir.) (damages available), cert. denied, 459 U.S. 909 (1982); Sabo v. O'Bannon, 586 F. Supp. 1132, 1138 (E.D. Pa. 1984) (damages available upon proof of discriminatory intent); Hurry v. Jones, $560 \mathrm{~F}$. Supp. 500, 511-12 (D.R.I. 1983) (damages available), rev'd in part on other grounds, 734 F.2d 879 (1st Cir. 1984); Wilder v. City of New York, 568 F. Supp. 1132, 1136 (E.D.N.Y. 1983) (damages available without proof of discriminatory intent); Christopher N. v. McDaniel, 569 F. Supp. 291, 296 (N.D. Ga. 1983) (damages available); Gelman v. Department of Educ., 544 F. Supp. 651, 653-54 (D. Colo. 1982) (same); Hutchings v. Erie City \& County Library Bd., 516 F. Supp. 1265, 1268.69 (W.D. Pa. 1981) (same); Patton v. Dumpson, 498 F. Supp. 933, 937-39 (S.D.N.Y. 1980) (same); see also Ciampa v. Massachusetts Rehabilitation Comm'n, 718 F.2d 1, 5 (1st Cir. 1983) (assuming without deciding that section 504 provides damages remedy). But see Longoria v. Harris, 554 F. Supp. 102, 106-07 (S.D. Tex. 1982) (damages remedy not available); Ruth Anne M. v. Alvin Indep. School Dist., 532 F. Supp. 460, $469-73$ (S.D. Tex. 1982) (damages remedy would frustrate underlying legislative purpose); Carter v. Independent School Dist. No. 6, 550 F. Supp. 172, 174 (W.D. Okla. 1981) (damages unavailable under Rehabilitation Act); Boxall v. Sequoia Union High School Dist., 464 F. Supp. 1104, 1112 (N.D. Cal. 1979) (although the Act was probably intended as private supplement to government enforcement, it does not provide new entitlement to damages).

62. 673 F.2d 969 (8th Cir.), cert. denied, 459 U.S. 909 (1982).

63. Id. at 978.

64. Id. at 979.

65. 569 F. Supp. 291 (N.D. Ga. 1983).

66. Id. at 296 (citing Patton v. Dumpson, 498 F. Supp. 933, 937 (S.D.N.Y. 1980)).

67. 532 F. Supp. 460 (S.D. Tex. 1982).

68. Id. at 471 .

69. Id. 
enforceability of section 504, the Ruth Anne court stated that an award of compensatory relief would contravene the goal underlying the Rehabilitation Act. ${ }^{70}$ The court explained:

$[T]$ he Court does not perceive a damage remedy as entirely consistent with the legislative purpose underlying the Rehabilitation Act. Congress enacted the Rehabilitation Act to promote and expand opportunities in the public and private sectors for handicapped individuals. Congress sought to achieve this purpose in Section 504 of the Act by conditioning the receipt of funds on the promise of equal opportunities in programs or services so funded. However, the implication of a damage reinedy would portend a potentially massive financial hability upon recipients of federal funds, possibly in excess of the amount of funds received. This exposure could serve a significant disincentive to the solicitation or acceptance of federal financial assistance, and hence a significant deterrent to the promotion and expansion of opportunities for handicapped individuals through funding legislation. ${ }^{11}$

The Ruth Anne court tacitly assumed that a danages remedy would be available im every case in which a section 504 violation was proved. By separating the question of the availability of relief from the standard for recovery, however, the Ruth Anne court simply set up a straw man which it could easily knock down. The availability of a danages rennedy in a section 504 action, if appropriately limited, is fully consistent with the congressional purpose of enhancmg group opportunity. ${ }^{72}$

4. The Supreme Court. Although the Supreme Court has routinely permitted a damages remedy under other statutes enacted by Congress to guarantee the civil rights of various classes of American citizens, ${ }^{73}$ the Court has not rendered an opinion specifically addressing the availability of a damages remedy under section 504.74 In fact, the

70. Id. at 473.

71. Id; see also Longoria v. Harris, 554 F. Supp. 102, 106 (S.D. Tex. 1982); Boxall v. Sequoia Union High School Dist., 464 F. Supp. 1104, 1112 (N.D. Cal. 1979).

72. See infra notes 100-20 and accompanying text. The vitality of the Ruth Anne conclusion is in doubt, even in the court that decided the case. Ruth Anne was decided before the Supreme Court announced its decision in Guardians Ass'n. v. Civil Serv. Comm'n, 463 U.S. 582 (1983). In Guardians, a majority of the Justices took the position that compensatory relief is available in title VI actions. See infra notes 78-83 and accompanying text. Because section 505(b) of the Act, 29 U.S.C. $\$ 794 a(a)(2)$ (1982), makes all of the remedies provided to plaintiffs under title VI available under section 504, a significant issue was not considered in Ruth Anne.

73. See, e.g., Albemarle Paper Co. v. Moody, 422 U.S. 405, 417-25 (1975) (availability of damages under title VII of the Civil Rights Act of 1964, 42 U.S.C. $\$ \$ 2000 \mathrm{e}$ to $2000 \mathrm{e}-17$ ); Johnson v. Railway Express Agency, 421 U.S. 454, 459-60 (1975) (availability of compensatory and punitive damages under 42 U.S.C. § 1981); Sullivan v. Little Hunting Park, Inc., 396 U.S. 229, 238-40 (1969) (permitting damages under 42 U.S.C. $\$ 1982$ ).

74. In Snith v. Robinson, 468 U.S. 992,1020 n.24 (1984), the Court stated: "Without expressing an opinion on the natter, we note that courts generally agree that damages are available under $\S 504 \ldots .$. 
Court recently declined to decide the extent to which a section 504 plaintiff could recover damages. In Consolidated Rail Corp. v. Darrone, ${ }^{75}$ the plaintiff sued his former employer for compensatory relief, alleging that the railroad had violated his rights under section 504 by refusing to rehire him following a work-related accident that left him unable to use one of his arms. ${ }^{76}$ The defendant argued that the case had been mooted by the death of the plaintiff. The Court disagreed with the defendant. Expressly reserving the question of the extent of a damages reinedy, it held that the case was not nnoot because section 504 authorizes an equitable action for back pay where the plaintiff alleges intentional discrimination. ${ }^{77}$

Although the Supreme Court has not yet found it necessary to define the scope of relief available under section 504, the availability of a damages remedy under that section can be logically inferred from the separate opinions in Guardians Association v. Civil Service Commission. ${ }^{78}$ In Guardians, black and Hispanic neinbers of New York City's police department brought suit to challenge the department's "last hired, first fired" employment policy. These plaintiffs contended that job layoffs resulting from the policy constituted racial discrimination in the workplace in violation of title VI. ${ }^{79}$ Directing its attention to the renedies available under the statute, a majority of Court agreed that compensatory relief may be awarded in title VI actions. ${ }^{80}$ Because section 505(a)(2) of the Rehabilitation Act provides that title VI remedies are to be available to section 504 claimants, Guardians implies by analogy the existence of compensatory rehef under section $504 . .^{81}$

\footnotetext{
75. 465 U.S. 624 (1984).

76. Id. at 628 .

77. $I d$. at $630-31$.

78. 463 U.S. 582 (1983).

79. Id. at $585-86$.

80. Id. at 607 n.27 (opinion of White, J., announcing the judgment of the Court).

81. It might be asserted that despite section 505(a)(2), Guardians does not support the existence of a damages remedy under section 504 because the Rehabilitation Act and title VI proscribe diferent types of discrimmation. Indeed, title VI prohibits employment related racial discrimination, a form of unequal treatment that arguably results more from intentional disfavor than does unequal treatment of the handicapped. Thus, a more potent remedy may have been made available under title VI in order to discourage such purposeful misconduct. See infra notes $92-93$ and accompanying text. Nevertheless, courts, including the United States Supreme Court, have generally referred to section 505(a)(2) when contemplating the relief available to successful section 504 complainants. These courts have expressly rehied on the literal wording of section 505(a)(2). See, e.g., Consolidated Rail Corp. v. Darrone, 465 U.S. 624, 631 (1984); Carter v. Orleans Parish Pub. Schools, 725 F.2d 261, 264 (Sth Cir. 1984); Sabo v. O'Bannon, 586 F. Supp. 1132, 1137 (E.D. Pa. 1984).
} 


\section{STANDARDS FOR Recovery OF COMPENSAToRy DAMAges}

Guardians did not suggest that every complainant who presents proof of title VI violations will recover compensatory relief. Despite the argument advanced by four of the Justices that both prospective and retroactive rehief were fully available to title VI plaintiffs without regard to intent, 82 a majority of the Court limited compensatory awards to cases in which the defendant had deliberately discriminated. ${ }^{83}$

Relying on the Guardians opinion and the language contained in section 505(a)(2) of the Rehabilitation Act, some courts have held that only plaintiffs injured by intentional violations of section 504 inay receive compensatory relief. ${ }^{84}$ As the Supreme Court recently cautioned however, "[T]oo facile an assimilation of Title VI law to $\S 504$ must be resisted." 85 Altliough the recognition in Guardians that compensatory rehef is available under title VI strongly suggests that danages are recoverable under section 504, to limit compensatory relief to situations involving intentional misconduct seems imappropriate, if not unsound, when applied to section 504 plaintiffs. Section 505(a)(2) merely provides that the "remedies, procedures, and rights set forth in title VI" are available to section 504 plaintiffs. ${ }^{86}$ Nothing in section 505(a)(2) requires that a 504 plaintiff seeking a certain form of rehef make a showing of all the elements necessary for the same rehef in a title VI dispute. ${ }^{87}$ Indeed, in

82. Guardians, 463 U.S. at 626-34 (Marshall, J., dissenting); id. at 636-39 (Stevens, J., joined by Brennan and Blackmun, JJ., dissenting).

83. Id. at 597-603 (opinion of White, J., announcing the judgment of the Court, joined in part by Rehnquist, J.); id. at 610-11 (Powell, J., joined by Burger, C.J., concurring) (arguing that no private right of action exists uuder title VI); id. at 612 (O'Connor, J., concurring). A majority of the Justices also were of the opinion that title VI was in fact only violated by intentional discrimination. Id. at 610-11 (Powell, J., jomed by Burger, C.J., and in part by Rehnquist, J., concurring); id. at 612 (O'Connor, J., concurring); id. at 641-42 (Stevens, J., joined by Breunan and Blackmun, JJ., dissenting). Only Justices White and Marshall believed that a violation of title VI was proven by a showing of discriminatory effects. Id. at $584 \mathrm{n} .2$ (opinion of White, J., announcing the judgment of the Court); id. at 623 (Marshall, J., dissenting). White, however, would award ouly prospective relief in such situations. Id. at 602-03 (opinion of White, J., announcing the judgment of the Court). Three Justices argued that a showing of discriminatory effects would be sufficient to prove a violation under the regulations issued under title VI. Id. at 643-45 (Stevens, J., jomed by Brennan and Blackmun, J.J., dissenting). Together with White and Marshall, a different inajority thus exists for the award of prospective relief upon a showing of discriminatory effects.

84. See Carter v. Orleans Parish Pub. Schools, 725 F.2d 261, 264 (5th Cir. 1984); Marvin H. v. Austin Indep. School Dist., 714 F.2d 1348, 1356-57 (5th Cir. 1983); Sabo v. O'Bannon, 586 F. Supp. 1132, 113738 (E.D. Pa. 1984). But see Wilder v. City of New York, 568 F. Supp. 1132, 1136 (E.D.N.Y. 1983) (discriminatory intent unnecessary for award of damages).

85. Alexander v. Choate, 105 S. Ct. 712,717 n.7 (1985).

86. 29 U.S.C. $\S 794 \mathrm{a}(2)(1982)$.

87. In Consolidated Rail Corp. v. Darrone, 465 U.S. 624 (1984), for example, the Court rejected the imposition on section 504 of the "primary objective" requirement of title VI. Id. at 635. That requirement limits the applicability of title VI to employment practices where the "primary objective" of federal financial aid is to provide employment. 42 U.S.C. $\$ 2000 \mathrm{~d}-3$ (1982). 
Alexander v. Choate, ${ }^{88}$ the Supreme Court recognized that although a inajority in Guardians held that a violation of title VI requires intentional discrimination, ${ }^{89}$ the reach of section 504 is not similarly confined and extends to some forms of unintentional discrimination. ${ }^{90}$ The Court recognized that title VI and section 504 address historically and socially distinct types of discrimination through statutory prohibitions that differ in coverage. ${ }^{91}$ Accordingly, the intent requirement announced in Guardians should not control the determination whether compensatory relief is available under section 504 .

\section{A. An Intent Requirement.}

Both title VI and section 504 resulted from congressional efforts to end unfavorable treatment of classes historically subjected to discrimination. The disfavor that handicapped persons generally face, however, differs froin that which the black commumity encounters. Uulike blacks, disabled persons do not suffer froin unequal treatment stemming froin overt discriminatory amimus.92 Instead, handicapped individuals are often denied equal opportumity because of mattention to their special needs. ${ }^{93}$ The absence of curb ramps or the construction of narrow walkways, for example, frequently result from oversights and are not part of a deliberate strategy to disfavor disabled persons. Congress recognized this aspect of handicapped discrimination, stating: "[T]he American people are simply unfamiliar with and insensitive to difficulties confronted by handicapped individuals and lack adequate knowledge about their potential for contribution to society." 94

Thus, the statutory scheme that Congress created acknowledges the modest role that intent plays in discrimination against the handicapped. In order to prove a violation of section 504, a plamtiff must show that he

88. 105 S. Ct. 712 (1985).

89. Id. at 716-17; see also supra note 83 and accompanying text.

90. Alexander, $105 \mathrm{~S}$. Ct. at 717-21. For a discussion of the type of unintended discrimination that violates section 504, see infra notes 100-20 and accompanying text.

91. Alexander, $105 \mathrm{~S}$. Ct. at 718-19; see also infra notes 92-94, 97-99 and accompanying text.

92. See J. JONES, PREJUDICE AND RACISM 3-4 (1972) (racial discrimination results from "those actions designed to maintain" whites' favored position at expense of other groups) (emphasis added). Jones acknowledges that some forms of institutional racism may not be intended. Id. at 6, 148. The Supreme Court also has rccognized that racial discrimination frequently results from overt racial animus. See General Bldg. Contractors Ass'n v. Pennsylvania, 458 U.S. 375, 386-88 (1982). See generally Wegner, supra note 5, at 436.

93. See infra note 94; see also Wegner, supra note 5, at $429-34$ (describing the differing historical contexts of racial and handicap discrimination).

94. S. REP. No. 319, 93d Cong., 1st Sess. 2 (1973); see also Alexander v. Choate, 105 S. Ct. 712, 718 (1985) (noting Congress's perception that discrimination against the handicapped is largely inadvertent). 
or she is a "handicapped person" under the Act, who is "otherwise qualified" for participation in a program receiving federal financial assistance, and who is being excluded from participation in, being denied the benefits of, or being subjected to discrimination under the program solely by reason of his or her handicap..$^{95}$

Requiring a showing of discriminatory intent as a requisite for compensatory relief is consistent with the type of prejudice title VI proscribes, because racial discrimination tends to be dehiberate rather than inadvertent. 96 Thus, compensatory rehef remains available to discourage or to provide reparation in cases involving such discrimination. Given the often inadvertent nature of the unequal treatinent proscribed by section 504, however, restricting damage awards under that section to cases involving discriminatory purpose effectively precludes recovery of damages by a vast number of section 504 claimants. Such a damages remedy would be a hollow deterrent; because individual plaintiffs would rarely recover monetary damages, the threat of an adverse judgment would provide a weak incentive to federally funded programs to avoid section 504 violations.

Furthermore, though Congress expressly limited title VI's coverage to only those federally funded programs whose "primary objective" was to provide employment, ${ }^{97}$ section 504 contains no such limitation, covering instead "any program or activity receiving Federal financial assistance."98 A requirement of discriminatory intent as a requisite for compensatory relief would drastically reduce the protection sucli expansive coverage was designed to afford. Many disabled citizens who sustained losses from inadvertent denials of opportunities to enjoy federally aided educational, reliabilitative, transportation, recreational, and employment services would not be able to bring a suit for dainages despite the extensive coverage that section 504 accords and despite the necessity of encouraging private enforcement. 99 Without the deterrent effect that dannages hability provides, disfavorable treatment is likely to recur. Though widely applicable, section 504 will still not respond adequately to the needs of its benefited class if a plaintiff is required to prove intentional discrimination in order to recover damages.

95. 29 U.S.C. § 794 (1982); see also Doe v. New York Univ., 666 F.2d 761, 774-75 (2d Cir. 1981); Pushkin v. Regents of the Univ. of Colo., 658 F.2d 1372, 1384 (10th Cir. 1981).

96. See supra note 92.

97. 42 U.S.C. $\S 2000 \mathrm{~d}-3$ (1982).

98. 29 U.S.C. $\$ 794$ (1982) (emphasis added). In Consolidated Rail Corp. v. Darrone, 465 U.S. 624, 635 (1984), the Supreme Court held that the "primary objective" limitation of title VI was not applicable to section 504 by virtue of the 1978 amendments to the Rehabilitation Act.

99. See supra notes $57-60$ and accompanying text. 
B. An Effects Test.

In the Rehabilitation Act Congress concentrated on helping handicapped persons overcome the effects of discrimination; it appeared less concerned with whether the person responsible for the unequal treatment acted intentionally. ${ }^{100}$ It is therefore logical to assume that compensatory relief should be available whenever discriminatory effects are proven.

It can be argued, however, that requiring proof only of discriminatory effects will result in the situation portended by the Ruth Anne court: potential recipients of federal funds shunning such funds out of fear of potential damages liability. ${ }^{101}$ Indeed, the elements needed to establisli a violation of section 504 necessarily satisfy an effects requirement. ${ }^{102} \mathrm{~A}$ claimant has demonstrated discriminatory effects once he or she proves that, as an "otlerwise qualified handicapped individual," 103 he or she has been demied full participation in a federally assisted activity solely because of a handicap. ${ }^{104}$ Thus, under a standard that requires a showing of discriminatory effects, any complamant who could prove a violation of section 504 would be entitled to compensatory relief.

Close examination of the responsibilities of fund recipients under the Act, however, reveals that this concern for widespread liability under an effects test is exaggerated. As the Supreme Court recently recognized in Alexander v. Choate, ${ }^{105}$ not all showings of discriminatory effects constitute violations of section 504. ${ }^{106}$ Section 504 only prolibits discrimination against an "otherwise qualified" liandicapped individual "solely by reason of his handicap."107 The Supreme Court lias stated that this language means that funded programs cannot assume that an individual is not qualified for participation in the program merely because that individual is handicapped. ${ }^{108}$ Thus, although "[s]ection 504 seeks to assure evenhanded treatment and the opportunity for handicapped individuals to participate in and benefit from programs receiving federal assist-

100. See supra notes 40-42, 94-95 and accompanying text; see also Wegner, supra note 5, at 43334 (section 504 is concerned with discriminatory effect, not violator's state of mind).

101. See supra notes 67-71 and accompanying text.

102. See supra note 95 and accoinpanying text.

103. 29 U.S.C. \$ 794 (1982).

104. Id.

105. 105 S. Ct. 712 (1985).

106. Id. at $720-21$.

107. 29 U.S.C. $\$ 794$ (1982) (emphasis added).

108. Southeastern Community College v. Davis, 442 U.S. 397, 405 (1979). The Court defined "otherwise qualified" as follows: "An otherwise qualified person is one who is able to ineet all the program's requirements in spite of his handicap." Id. at 406. 
ance," 109 it requires neither that programs totally disregard handicaps ${ }^{110}$ nor that they make more than reasonable accommodations for handicapped individuals. ${ }^{111}$

Though not expressly identified in section 504, the existence of a duty of reasonable accommodation is now well established. In Southeastern Community College v. Davis, 112 the Supreme Court held that section 504 does not compel administrators to initiate "substantial modifications" of tlieir federally aided activities for tlie sake of a disabled person."13 The Court added, however, that "situations may arise wliere a refusal to modify an existing program might become unreasonable and discriminatory."114 Thus, although it lield that section 504 does not require major adjustment of the essential elements of a federally assisted program when sucli adjustment inay prove too expensive or too fundamental, the Court inılied that the statute does require program operators to institute modest modifications that entail no severe financial or administrative difficulties. ${ }^{115}$ More recently, in Alexander v. Choate, ${ }^{116}$ the Court expressly endorsed the reasonable accommodation approach of Southeastern Community College as striking an appropriate balance between the riglits of handicapped individuals to be imtegrated into society and the imterests of federal grantees in the continued integrity of their programs. ${ }^{117}$

A sliowing that a federal fund recipient has violated section 504 thus requires more tlian a demonstration of discriminatory effects. Plaintiffs must show that they were "otlierwise qualified." Fund recipients can rebut an allegation of discrimination by demonstratimg that their actions were motivated by legitimate considerations, sucli as cost and safety, and

109. Alexander v. Choate, 105 S. Ct. 712, 722 (1985) (citing Southeastern Community College v. Davis, 442 U.S. 397 (1979)).

110. Southeastern Community College v. Davis, 442 U.S. 397,405 (1979).

111. See infra notes $112-17$ and accompanying text.

112. 442 U.S. 397 (1979).

113. Id. at 413. For a recent court opmion discussing the extent to which administrators should provide accommodation, see Mantolete v. Bolger, 767 F.2d 1416, 1420, 1423-24 (9th Cir. 1985).

114. Southeastern Community College, 442 U.S. at 412-13.

115. Id. at 412; see also New Mexico Ass'n for Retarded Citizens v. New Mexico, 678 F.2d 847, 853 (10th Cir. 1982).

116. 105 S. Ct. 712 (1985).

117. Id. at 720-21. Rules promulgated under section 504 refer to this duty. Two such regulations, for example, provide: "A [federal aid] recipient shall make reasonable accommodation to the known physical or mental limitations of an otherwise qualified handicapped applicant or employee unless the recipient can demonstrate that the accommodation would impose an undue hardship on the operation of its program." 34 C.F.R. $\$ 104.12$ (a) (1985) (Department of Education rules); see also 45 C.F.R. $\$ 84.12$ (a) (1985) (identical language in HHS rules). 
not solely by the plaintiff's handicap. ${ }^{118}$ Where no such justifications exist, and full participation in a federally funded prograin could have been accomplished without unreasonable modification thereof, section 504 is violated $^{119}$ and coinpensatory relief is appropriate and necessary for the enforcement of its antidiscrimination mandate.

Nor should such hability be unexpected. The directors of all federally aided programs have the legal responsibility of avoiding liability under section 504: For example, the regulations promulgated under section 504 place on fund recipients a duty to conduct an evaluation of their programs for section 504 compliance. This entails consultation with interested persons, including handicapped individuals or organizations representing them. ${ }^{120}$ Limiting section 504 plaintiffs to prospective relief would dissuade federal fund recipients froin attempting to discover, evaluate, and remove discriminatory obstacles. Far froin being inconsistent with the intent of Congress, damage awards are necessary to fulfill the congressional purpose.

\section{CONCLUSION}

In determining whether section 504 affords a private right of action for money damages, consideration of congressional purpose is paramount. Section 504 requires that recipients of federal funds provide liandicapped persons equal opportumity. In selecting this sclieme of regulation, Congress sought to protect group riglits and advance group opportunities. Group opportunities are advanced when prograins comply with section 504; they are not advanced when programs reject federal funds as an alternative to complying with the Act.

Because administrative remedies and prospective relief generally are far from adequate to provide an incentive for coinpliance with section 504, such incentive must be supplied by the availability of private actions for money dainages. In keeping with congressional purpose, however, the riglit to money damages must be qualified. The need to provide an incentive to programs to make the reasonable accommodations required under section 504 must be balanced against the threat that a great number of successful damage actions will cause programs to reject federal aid, and, consequently, to deny participation to the handicapped.

118. See Southeastern Community College v. Davis, 442 U.S. 397, 413 (1985) (recognizing as legitimate a university admissions policy aimed at insuring that no graduate pose a danger to the public in a professional role); see also Wegner, supra note 5 , at $444,451.52$ (use of cost, safety or other justification to rebut allegation of discrimination).

119. See Wegner, supra note 5, at 444 (absent justification, it can be assumed refusal to accommodate was solely motivated by the handicap).

120. See, e.g., 45 C.F.R. $\S 84.6$ (c) (1985) (HHS rules imposing duty to self evaluate). 
This note has examined two standards for allowing recovery of money damages: intentional discrimination and discriminatory effects. Only the latter standard can reach the type of discrimination Congress sought to proscribe and provide the proper level of incentive to federally funded programs to provide reasonable accommodation for the handicapped. Without such an incentive, the Act's guarantee of equal opportunity for the handicapped is a hollow promise.

John D. Briggs 
